\title{
EXHIBITING EVOLUTION AN ESSAY UPON THE MUSEUM'S SUBJECTIVITY
}

\author{
Giovanni Pinna \\ Former director of the natural history museum of Milano
}

\begin{abstract}
A museum is not only a physical place, a mere container of fragments of the cultural heritage. It is above all a unity of knowledge whose task of scientific research and analysis of the collections leads to an original interpretation of the world, to a specific culture, typical of each museum. Through its permanent exhibitions or any other means at its disposal, each museum conveys its cultural specificity to the visitor, a specificity which is different to that of other museums and does not intend to be objective. This paper aims to prove all the above by showing how, in different times and places, three important museums displayed three examples of evolution obtained form paleontology developing a totally subjective interpretation of the evolutionary process.
\end{abstract}

KEY WORDS: Evolution. Cladistic. Orthogenesis. Museums. Paleontology.

\section{EXHIBIENDO LA EVOLUCIÓN. ENSAYO SOBRE LA SUBJETIVIDAD DEL MUSEO}

\section{RESUMEN}

El museo no es sólo un lugar físico, un simple contenedor de fragmentos del patrimonio cultural, es, sobretodo, una unidad de conocimiento cuya labor de investigación científica y análisis de las colecciones conduce a una interpretación del mundo totalmente original, a una cultura propia de cada museo. Utilizando las exposiciones permanentes, o cualquier otro medio a su disposición, cada museo comunica al público su especifidad cultural, que es diversa de la de otros museos y no quiere ser objetiva. Esto es cuanto el artículo pretende demostrar ilustrando cómo, en tiempos y lugares diferentes, tres grandes instituciones museísticas mostraron al público tres ejemplos de evolución obtenida de la paleontología desarrollando una interpretación totalmente subjetiva del proceso evolutivo.

PALABRAS CLAVE: Evolución. Cladística. Ortogénesis. Museos. Paleontología.

Today's natural history museum displays are losing their identity. While scientific activity in these institutions continues to move forward, the separation between scientific staff, i.e. the curators responsible for the study and 
organization of collections, and communication staff, responsible for the creation of exhibits, makes it extremely difficult, if not impossible, to incorporate museum culture within displays. As I have written on several papers, ${ }^{1}$ there is an organisational problem regarding museums and museum methodology which tends to nullify the museum's intrinsic culture within the message it transmits to the public, a problem that is difficult to resolve because it is caused by the resistance which museum scientific staff display as regards any direct assumption of the role of cultural mediators.

This in turn leads to an inevitable homogenisation, not just of contents, but also of the form of museums - to such an extent that the only thing that seems to distinguish natural history museums in geographic regions that are very different from each other often seems to be nothing more than the language used to write the captions. Natural history museums are therefore virtually identical in their focus on the same subjects - conservation and documentation of biodiversity, environmental education, school didactics aimed at protecting the environment - which are treated from a universal perspective i.e. a perspective that tends to frame the subject and its discussion in absolute terms and dispense with any interpretation or alternative solution.

In this globalisation of problems and solutions all connection with local situations and the specific cultures of communities are naturally lost.

In an article dedicated to relations between politics and contemporary history museums, Hildegard Vieregg, at the time president of the ICOM International Committee for Museology (ICOFOM), argued that these institutions, together with documentation centres and memorial monuments,

«should all be based on accurate research; should promote and increase awareness through the transmission of information and explanation; and should conceive of exhibits (historical sources, authentic objects as well as documents and individual biographies) as specific items which serve as examples, given access to the past and link the totality of the real past to the present and the future.» ${ }^{2}$

Then, discussing the Bayerisches Armeenmuseum in Ingolstadt in particular, which opened in 1994 and is dedicated to the first world war, she felt that

1 PInNA, G. (1997), Fondamenti teorici per un museo di storia naturale, Milano, EDO, Jaca Book; PInNA, G. (2000), Scientific Research versus Public Exhibits: A Schizophrenic Aspect of Natural History Museums. In Ghiselin, M.T. \& LEVITON, A.E., Cultures and Institutions of Natural History, California Academy of Sciences, Memoir 25, pp. 329-332.

2 VIEREGG, H.K. (2000), Museology, contemporary history and politics, Icom Study Series, 8 , pp. 17-19, p. 19. 
the aim of the museum was to develop the political conscience of visitors, though she also added that the most difficult aspect was that «to develop a museum which respects historical truth, presenting the topics as objectively as possible. $\rangle^{3}$ The statements made by Vieregg are interesting for two reasons: first, because they indicate that some museologists have an idyllic and theoretical view of museums, despite the fact that it is often quite clear that these institutions are subject to dominating power systems; and secondly, because they demonstrate that part of the world of museums is still under the spell of historical positivism, which considers history to be an objective fact, views historic facts as objective and presumes that the task of the historian is to describe what occurred in the past without providing any interpretation. ${ }^{4}$

For non positivist historians, on the other hand, history is interpretation and not chronology. They argue that the same event can be interpreted and described in different ways by different historians, even if the latter base their analyses on the same sources and same documents.

«The history of the world must be rewritten from time to time (...) — as Goethe declared - But the need to do so does not arise because many things have been discovered, but because new opinions will be created when a person in a later age adopts views from whose vantage point the past may be surveyed and judged in a different way.» ${ }^{5}$

The historian's dilemma, in the specific case of a science historian, in his struggle to arrive at a degree of objectivity that can never be achieved, has been described by R. Hooykaas as follows:

«What method do we want then? An objective one. But objectivity is impossible! Without any doubt, it is impossible, as historiography is not a mere compilation of facts: the choice of material already implies an element of subjectivity and amounts to an evaluation. The fact that the historian of science is a scientist himself, influences his judgment on what is important or not. But in spite of this unavoidable influence of the historian's own political, educational, social, national, religious background and his personal character, we maintain the ideal of objectivity. Like all ideals it is unattainable, but, nevertheless, it should keep us in a holy dissatisfaction with ourselves.»6

\footnotetext{
3 VieregG (2000), p.17.

4 KRAGH, H. (1987), An introduction to the historiography of science, Cambridge University Press.

5 Cited KRAGH (1987), p. 45.

6 HooykaAs, R. (1970), Historiography of science, its aim and methods, Organon, 7 , pp. $37-49$, p. 49
} 
If historical interpretation is therefore subjective, no absolute historical truth can exist, which obliges us to interpret the museum and its information action in a manner that is very different from that outlined by Hildegard Vieregg i.e. if historic museums are places where the historical memory of a community or a nation is retained, as in the Bayerisches Armeenmuseum in Ingolstadt, we cannot argue that they are impartial institutions that are able to communicate the incommunicable, in other words historical truths.

A similar approach can be adopted for science and for scientific museums. Just as no historical truth exists, so there is no absolute scientific truth, both because each scientist has, within certain limits, his own truth, and because - as Karl Popper extensively argued - every scientific truth is transitory. Hence, as with the history museums, science museums too, despite every effort imbued with honesty and goodwill, cannot communicate truths, but only subjective hypotheses and interpretations. The same thing holds for museums of art, and we can comprehensively extend the concept to all museums when we consider that these institutions are not passive but active subjects i.e. they are not just deposits or temples of contemplation but carry out complex functions that encourage education and knowledge about the heritage of a community: selection, analysis and conservation of objects, creation and communication of meanings.

Everyone agrees that museums are places where objects that represent the past, the history and identity of a community are conserved, and many agree that they are also a means of communication via which the symbolic meanings that inform these objects are disseminated within the community and transferred to future generations. On the other hand, due account is not always taken of the fact that these institutions also carry out a significant role in the creation of these meanings, contributing to the construction of the cultural heritage of communities, their memories and their identities. The power to create cultural heritage is enjoyed by museums as a result of their being centres of scientific elaboration, places of research where objects that are potentially appropriate as aspects of cultural inheritance are selected, analysed and inserted in precise space-time contexts, becoming an integral part of a historic, scientific and artistic narrative. It is at this moment that a museum's intrinsic inability to be impartial and objective comes into play, in the sense that during the creation of heritage it produces entirely personal scientific and historical truths. In this sense a museum is a true producer of culture, since it creates its own specific and original culture through a combination of the individualities that act within the museum, each of which is in turn specific and original. 
The result of all this is that each museum, creating, owning and communicating a real and original truth, should be different from every other museum. Which is entirely contrary to what has occurred in recent years as regards museology. The victim of architects who see museums solely as an external skeleton, this institution is losing its soul, becoming a mere symbol of itself. But things were not always like this. Until the quite recent past museums were constructed by architects who, as far as possible, interpreted the form of a building on the basis of what the contents of the museum would be, and they were managed by scientists, historians and philosophers who organised the galleries' displays on the basis of the image of the world they themselves had created, a vision of the world which therefore could not fail to be original and entirely partial. This is abundantly clear for museums of natural history, each of which, prior to the kind of homologation towards a uniform model that has developed in recent years, had its own particular truth to tell.

As an indication of how natural history museums used to see their vocation as that of expressing their own specific cultures in their exhibits, three examples are provided below, taken from three of major natural history museums: the Muséum National d'Histoire Naturelle in Paris, the American Museum of Natural History in New York and the Natural History Museum in London [which at the time vaunted the even more prestigious name of British Museum (Natural History)]. The examples refer to different years but involve a similar subject: the illustration of evolution using a palaeontological approach. They demonstrate how, in each museum, the subject of evolution was treated and offered to the public on the basis of scientific ideas that had been elaborated or shared by those who carried out their work scientifically in the museums.

Paris 1898: Gallery of Palaeontology in the Muséum National D'HisTOIRE NATURELLE

On 21 July 1898 a large building was inaugurated in Paris, located within the boundaries of the Jardin des Plantes. It was built to contain the new galleries of comparative anatomy, palaeontology and anthropology in the Muséum National d'Histoire Naturelle of Paris, conceived by Albert Gaudry, museum's full professor in palaeontology. A palaeontologist who was famous for his studies on fossil mammals, and above all the first french darwinian evolutionist, Gaudry had struggled for more than a quarter of a century to provide the museum with a palaeontological gallery since he was convinced of the need to illustrate to the public at large, through fossils, the history and 
very idea of evolution - an idea which in the second half of the XIX century had led to a crisis of conscience in many people and, after thousands of years of centrality, brought the question of man's relationship with his natural environment fully to the fore.

« (...) en dehors d'un petit groupe de savants et de penseurs, — he wrote- la paléontologie est encore peu connue. La presse destinée au grand public ne parle presque jamais en France des découvertes de fossiles, si extraordinaires qu'elles soient; elle ne s'intéresse qu'aux recherches d'archéologie. Jusqu'à présent, dans les classes supérieures de nos lycées, on ne s'occupait ni de géologie, ni de paléontologie, de sort que les élèves entraient dans la classe de philosophie ignorant l'importance de ces sciences pour les questions d'origine. $\rangle^{7}$

Gaudry had great faith in palaeontology. He felt it could provide a detailed reconstruction of the evolutionary history of organisms, so much so that he declared «l'homme ne peut lire dans l'avenir (...) ma il peut essayer de lire dans le passe». ${ }^{8}$ His faith in the ability of palaeontology to reconstruct the events of the past, together with his particular vision of evolutionary processes, guided Albert Gaudry in his arrangement of fossils in the new gallery, and gave a precise form and meaning to his exhibition.

Gaudry did not fully agree with Darwin's ideas. More specifically, he rejected the mechanism of natural selection which inevitably led to randomness. For him a general plan had dominated the development of life during the course of geological eras, gradually and progressively modifying the animal world. According to the palaeontologist of the Muséum, the similarities between animals of successive epochs demonstrated that evolution consisted in the progressive and gradual appearance of new features which, over the course of time, led to the formation of new systematic entities. Each systematic entity therefore constituted a transition between an ancestor and a descendant, forming a ring in a chain that linked the whole history of life together, a long chain that he sought to describe in his main palaeontological work, Les enchaînements du Monde animal, published between 1878 and $1890 .{ }^{9}$

The new palaeontological display had to faithfully reflect the vision of evolution as he had described it in his Enchainements. For this reason he ordered a 75 metres long gallery, where the architect Ferdinand Durtert

7 Gaudry, A. (1898), Le Nouveau Musée de Paléontologie, Revue des deux mondes, pp. 799-824, p. 799

8 GAUDRY (1898).

9 GAUdRY, A. (1878-1890), Les enchaînements du Monde animal, Paris, Masson, 3 vols. 


\section{EXHIBITING EVOLUTION AN ESSAY UPON THE MUSEUM'S SUBJECTIVITY}

«a eu le mérite de subordonner l'arrangement des galeries au seul intérêt de la science. Il ne les a séparée par aucune avance parce que, l'évolution des êtres ayant été continue, il importe que le collections forment des enchaînements interrompus» ${ }^{10}$

He then arranged the fossils chronologically and not in systematic order, as was the practice in many museums, with the precise intention of providing an image of this astounding sequence of organisms over time.

«La classification chronologique des fossiles de notre musée - he wrotepermet au visiteur d'embrasser au premier coup d'œil le développement progressif du monde, car au commencement de la galerie où sont placés les plus anciens êtres, il ne rencontre que des types simple, chétifs ; à mesure qu'en pénétrant dans la galerie il trouve des créatures de plus en plus récentes, il voit des types plus avancés ; et, vers le fond de la galerie qui renferme les derniers venus, il aperçoit les types les plus perfectionnés. La classification adoptée est la classification la plus usuelle, celle qui a été proposée par les congrès internationaux de géologie. En parcourant notre galerie, on se trouve tour à tour dans le Primaire, puis dans le Secondaire, puis dans le Tertiaire et enfin dans de Quaternaire.» ${ }^{11}$

Gaudry had achieved his goal and could declare «que notre galerie va présenter l'histoire des enchaînements du monde animal.»12

«Ce qui frappe quand on entre dans cette grande salle qui renferme des milliers de témoins de la vie d'autrefois - as a description of the gallery states, made the same year it was opened- c'est son air de grandeur. Des séries de meubles à tiroirs, surmontés de vitrines, s'alignent en son milieu, tandis que des armoires en fer, mais aux portes, aux parois et aux rayon de verre (...) forment une rangée continue sur le pourtour (...) Des grands échantillons montés sur pivots mobiles s'échelonnent au dessus des armoires. Les Grands vertébrés font face à l'entrée et ce que l'on aperçoit d'abord c'est la large gueule du Pareiasaurus arqué sur ce pattes (...) a gauche on remarque un Ichthyosaure avec un fœtus, à droite un Téléosaurus admirable de conservation. Plus loin on voit de fémurs de Dinosauriens provenant d'Amérique et de Madagascar qui dénotent des animaux ayant de 12 à 15 mètres de long (...) En continuant à s'avencer vers le fond de la salle on rencontre un squelette complet de Rhinoceros, trouvé aux environs de Gennat, puis un superbe Mastodon angustidens avec ses quatre défenses, provenant de Sansan (Gers.) Dans le temps géologiques, vivaient en Grèce de nombreux troupeaux de Ruminants, de Cerfs, de Girafes, de Rhinoceros et d'Hipparion (...) On a Groupé

10 GAUDRY (1898), p. 809.

11 GAUDRY (1898).

12 GAUDRY (1898), p. 808. 
cet ensemble de fossiles (excavated at Pikermi and studied by Gaudy, author's note) au milieu de la galerie. Plus en arrière, le Magatherium, ce curieux Édenté de l'Amérique du Sud, s'appuie sur un arbre brisé par la foudre. Il est flanqué du bizarre Glyptodon, autre Édenté, dont l'énorme carapace fait penser aux Tortues. Vers le fond de la salle et la dominant de toute sa hauteur se dresse le majestueux Éléphant de Durfort trouvé dans le Gard et qui atteignait une hauteur de 4,50 m. Il faut signaler aussi le Dinotherium, ce Proboscidien dont la taille dépassait 5 mètres, le Cervus megaceros, qui possédait une ramure de 3 mètres et demi de large; le Dinoceras, si étrangement cornu, avec ses canines en forme de poignard, les Dinornis, ces oiseaux géants, sans ailes, de la Nouvelle-Zélande, ayant jusqu'à 3 mètres et demi de haut (...) Mais les plus grands animaux ne sont pas le seuls curieux. Il en est des milliers qui ont jadis peuplé les mers et les continents, et dont l'étude est des plus intéressantes. On les a disposés dans l'ordre suivant lequel ils sont apparus sur la terre. Les premiers que l'on rencontre, en pénétrant dans la galerie, sont les plus anciens que l'on connaisse, puis, à mesure que l'on marche cers l'autre extrémité, on passe en revue des êtres de plus en plus récents, de sorte que l'on arrive à des espèces qui, comme l'hyène, l'ours et le Dinornis, ont été contemporaines de l'homme. Cette revue terminée, on peut se dire que l'om a vécu, en quelques instants, plusieurs centaines de millions d'années (...) Pour la commodité de l'étude, les temps géologiques ont été divisés en quatre ères: primaire, secondaire, tertiaire et quaternaire; chaque ère a été subdivisée a son tour en plusieurs autres, et dans chacune de ces nouvelles subdivisions, au nombre de 14, les animaux ont été classés suivant l'ordre zoologique. Chaque période embrasse ainsi un espace de temps assez long et l'on peut suivre facilement l'évolution des différents groupes d'êtres qui vivaient à ces époques successives (...) Le visiteur qui aura parcouru en détail cette galerie emportera la notion de ce qu'était la vie dans les temps géologiques et il aura un aperçu de la prodigieuse évolution des êtres qui se sont succédé à sa surface.» ${ }^{13}$

Apart from the inclusion of new materials, like the large cast of diplodocus, exhibited in 1908, which modified the original appearance of the gallery, its basic philosophy has remained unchanged, as Philippe Taquet formerly director of the palaeontology laboratory in the Muséum relates:

«les grands squelettes sont donc disposés selon un ordre chronologique, des plus anciens aux plus récents. Les vitrines latérales montrent côté jardin, le déroulement de l'évolution depuis les premiers vertébrés jusqu'à la diversification des principaux groupes de mammifères en passant par l'étape essentielle de la sortie des aux, de la conquête des milieux terrestres par les vertébrés, les vitrines latérales côté rue Buffon, présentent les grands gisements fouillés et étudiés par le paléontologues du Muséum: sites Permien du Massif Central, Jurassique de Canjuers dans

13 Glangeaud, Ph. (1898), Les Nouvelles Galeries du Muséum. II Galerie de paléontologie, La Nature, pp. 307-310 
le Var, Paléogène de Cernay dans la Haute.Marne, Eocène du gypse du Bassin de Paris, Pléistocène d'Amérique du Sud.» ${ }^{14}$

NEW YORK 1908: THE EXHIBIT ON THE EVOLUTION OF EQUIDAE IN THE AMERICAN MUSEUM OF NATURAL HiSTORY

On 13 November 1908 in the Hall of Fossil Mammals of the American Museum of Natural History in New York, an exhibition was opened to the public dedicated to the evolution of the horse. The author of this exhibition was Henry Fairfield Osborn, president of the museum and one of the most eminent American palaeontologists of his time. The new sector replaced a previous illustration of the evolutionary history of the horse entitled Ancestry of the Horse, which showed, via the exhibit of specimens from successive geological epochs - two complete skeletons, and many skulls and limbshow the modern horse was derived from a small animal with four digits of the lower Eocene. $\rangle^{15}$

The history of the horse was considered the best example which palaeontology had up to that time provided, demonstrating the doctrine of evolution by natural selection and adaptation of animals to their environment, so the illustration of this evolutionary pathway also constituted a way to introduce the idea of evolution to the general public, without actually describing its mechanisms. The ancestry of this family — wrote William Diller Matthew, Assistant Curator of the Department of Palaeontology of Vertebrates in the museum of New York-

has been traced back to nearly the beginning of the Tertiary without a single important break. During this long period of time, estimated at nearly three millions of years, ${ }^{16}$ these animals passed through important changes in all parts of the body, but especially in the teeth and feet, adapting them more and more perfectly to their particular environment, namely the open plains of a great plateau region with their scanty stunted herbage, which is the natural habitat of the Horse. In the series of ancestors of the Horse we can trace every step in the evolution of those marked peculiarities of teeth and feet which distinguish the modern Horse from an ancestor

14 Taquet, P. (1995), Paléontologie et anatomie, Connaissance de l'art, 5 (82), pp. 44-54.

15 Matthew, W.D. (1902), The Hall of Fossil Vertebrates, The American Museum Journal, 2, p. 11, fig. pp. 9, 10. MATTHEW, W.D. (1903), The collection of fossil vertebrates, The American Museum Journal, 3, pp. 5-32, p. 18, fig. p. 23.

16 L'Hyracotherium, the oldest horse's ancestor, is about 50 million years old. 
which so little suggests a horse that, when is remains were first found forty years ago, the animal was named by the great palaeontologist Richard Owe, the Hyracotherium or «Coney-like Beast»... Commencing with the Hyracotherium, twelve stages ${ }^{17}$ have been recognized from as many successive formations, showing the gradual evolution of the race into its modern form, and each stage is characteristic of its particular geological horizon. $\rangle^{18}$

In his article of 1903 Matthews reported (figures on pages 14 and 18) a simplified version of the exhibit dedicated to the evolution of the horse's limbs, with respect to the evolutionary path in 12 stages discussed in an extensive manner in the text. The panel set out, in a horizontal linear series, the anterior and posterior limbs of Eohippus (Lower Eocene), Protorohippus (Middle Eocene), Epihippus (Upper Eocene), Mesohippus bairdi (Middle Oligocene), Mesohippus intermedius (Upper Oligocene), two species of $\mathrm{Me}$ richippus (Middle Miocene), Hypohippus (Upper Miocene), Hipparion (Lower Pliocene), an Equus (Pleistocene) and those of today's horse.

The study of the evolution of the horse was at the centre of interest among palaeontologists in the American Museum, who had brought together a large collection:

«hundreds of skulls and partial skeletons, thousands of jaws and tens of thousands of teeth and bones. They come from all parts of the world where fossil horses have been found, but chiefly from the Western Bad Lands. Some have been obtained by exchange with other museums or by purchase, but the greater part has been collected by expeditions which have been sent out year after year since $189 .{ }^{19}$

This collection had contributed, together with the study of numerous other sectors of the palaeontology of vertebrates, to the formation of those particular ideas which Osborn had concerning the mechanisms of evolution, ideas which, thanks to his pre-eminent position in the American Museum, he was able to illustrate in the displays of fossil vertebrates in the museum, in particular in the showcases dedicated to the history of equidae and that of the titanotheres.

17 In reality there were 11 development stages, since Matthews considered Hyracotherium, described on European fossils, and Eohippus, described on North America fossils, as two successive stages of evolution, when they are in fact the same species.

18 Matthew, W.D. (1903b), Illustration of evolution among fossil mammals. A.-The Horse, The American Museum Journal, 3, pp. 3-30.

19 Matthew, W.D. (1908), Exhibit illustrating the evolution of the horse, The American Museum Journal, 8 (8), pp. 117-122. 
Osborn was an exponent of that current of thought which interpreted evolution from an orthogenetic perspective i.e. as a linear process in which evolutionary changes are determined by forces within the organisms, which drive them to vary in predetermined directions, to a large extent independently of the environment. ${ }^{20}$ For Osborn the evolution of the horse was an example of this predetermined evolution. It had pushed the equidae to evolve, through the gradual appearance of modifications arranged in a rectilinear direction (which he called rectigradations), along a single line of descent that was characterised by a progressive increase in size, gradual loss of digits and modification of the teeth crown.

The showcases that he had made to exhibit the evolution of horses illustrated his particular view of evolutionary mechanisms, which were also very much in vogue at that time. The new exhibition was composed of two parts, one dedicated to the evolution of the horse in the wild, the other to its evolution in its domestic state. In the first part nine complete skeletons represented nine stages of evolution of the horse's ancestors in different geological periods, and numerous skulls and bones exhibited every intermediate variation from the oldest ancestors, no bigger than a terrier, to the modern descendants.

«The specimens on exhibition in the Museum — wrote Matthews - are arranged to show the gradual development of the peculiar characteristics which distinguish the horse from other animals, and especially the adaptation to swift running over the open plains which are the natural habitat of the animal. With each skeleton is placed a restoration showing the probable appearance and natural surroundings of the animal during life. The exhibit is further illustrated by models, diagrams and special series showing the evolution of certain parts of the skeleton. The restoration of extinct horses have been made by the well known animal painter, Mr.Charles R. Knight, under the supervision of Professor Osborn.» ${ }^{21}$

A double panel in this display, which shows the main modifications to the skull, teeth and limbs, was reported by Matthew and Chubb in $1913 .{ }^{22}$ Here the arrangement of the pieces that illustrate the subsequent modifications undergone by the various parts of the skeleton is no longer horizontal, but follows a vertical arrangement, which emphasises the linearity and continuity of the modifications over time.

20 PInNa, G. (1995), La Natura paleontologica dell'evoluzione, Torino, Einaudi.

21 MATTHEW (1908).

22 Matthew, W.D. \& ChubB, S.H. (1913), Evolution of the Horse, American Museum of Natural History, Guide leaflet series, n. ${ }^{\circ}$ 36, fig. pp. 36, 37. 
«In the years between 1908 and 1913 —wrote Ronald Rainger- Osborn used his position of power to make the American Museum a concrete expression of his scientific and social beliefs. As regards evolution, the author continues, Osborn took care to develop displays that included his interpretation of evolution. Again, the evolution of the horse provided one of the most significant examples. Having interpreted the history of the family of the horse in orthogenetic terms, Osborn used the museum's resources and his commitment to the education of the public to convey his ideas to the latter in a way that was impossible for the majority of scientists (...) (All the material which he had exhibited) embodied a clear and direct message: evolution from the small Eohippus in the Eocene through to today's modern Equus occurred in a gradual and linear way and demonstrated the regularity of the laws of nature. It was a message that had a long-lasting influence. Since the 1920s scientists, including Matthew and Gregory (who were students and collaborators of Osborn -Author's note), have rejected the orthogenetic interpretations. Nevertheless the exhibition in the museum and its message remained intact and influenced the public's perception concerning evolution at least until the $1950 \mathrm{~s} .{ }^{23}$

In other words, when the neodarwinian Modern Synthesis had already elaborated a new history for the horse and a new non determinist mechanism for its evolution, and the story of the horse had become a complex system of ramifications and migrations between North America, Europe and Asia, guided by a need to adapt to the changing natural environment and the random character of natural selection.

\section{LONDON 1979/1980: EXHIBITS ON DINOSAURS AND THE EVOLUTION OF MAN IN} THE NATURAL HiSTORY MUSEUM

Towards the second half of the 1970s a new methodology of organism classification began to become more widespread among palaeontologist, a methodology elaborated by the German entomologist Willy Hennig in $1950,{ }^{24}$ and which became more widely known to most scientists only in 1966, following the translation into English of the main work by this author. ${ }^{25}$

As with all postdarwinian classification systems, the new systematic by Hennig again sought to classify organisms from a phylogenetic perspective i.e. on the basis of their mutual relationships. However, while other systems use

23 RAINGER, R. (1991), An Agenda for Antiquity, Tuscaloosa, University of Alabama Press.

24 HeNniG, W. (1950), Grundzüge einer Theorie der phylogenetischen Systematick, Berlin, Deutscher Zentralverlag.

25 Hennig, W. (1966 ), Phylogenetic Systematics, Urbana, University of Illinois Press. 
morphological similarities to establish such relationships between groups, Hennig's method, known today as Phylogenetic Systematics or Cladistics, uses the identification of common ancestors as the sole criterion for grouping the taxa.

Hennig's methodology hypothesises that evolution consists in the ramification of phyletic lines according to a succession of dichotomous divisions, and that at each ramification the ancestral line ceases to exist, giving rise to two derived lines, neither of which represents the original line. In other words it presupposes a certain taxon, for example a species, disappears when the dichotomous ramification occurs, giving rise to two different taxa (for example two species, which are called sister species or brother groups). In this dichotomous subdivision the two lines derived from an ancestral phyletic line constitute a monophyletic group, since they comprise taxa that all descend from the same ancestor. Since only monophyletic groups are natural groups, for cladists the systematic consists in identifying such groups, while evolutionary history consists in the succession of the dichotomous subdivision points.

The identification of a given monophyletic group is carried out through the search for so-called synapomorphous characters, which are features derived from the direct progenitor, and not from ancestral progenitors, and which are therefore present only in representatives of the binary monophyletic group. The reconstruction of phylogeny according to the cladistic methodology therefore consists in identifying the dichotomies, retracing the synapomorphous features that are presumed to be found only in the descendants of the ancestor in which the feature is manifested for the first time, and in arranging such dichotomies in sequence. It is interesting to note that retracing the synapomorphous features does not have any temporal implication: in cladistic analysis fossils and living organisms are on the same temporal plane, since one assumes that the age of fossils does not provide any indication relative to the reconstruction of the evolutionary story due to the fragmented nature and uncertainty of paleontological documentation. Indeed it is held that the appearance of a given character in a fossil species does not necessarily have to be the «first» appearance of that character, and hence the dichotomy derived from that character is not necessarily to be assigned to the period of time corresponding to the age of the fossil.

Cladistics has enjoyed enormous success, which can be explained when one realises that Hennig's method also makes it possible for non specialists to acquire the data required for phylogenetic analysis, and the realisation of cladograms, i.e. phylogenetic trees that indicate relationships between groups, can be executed automatically on the computer, using specific programs. Over recent years cladistics has become a real scientific philosophy. Rightly 
or wrongly, it has forced itself on the attention of palaeontologists, to such an extent that today's most important scientific journals would be reluctant to accept an article in which the classification of organisms, or the evolutionary reconstruction of a group, is not carried out on a cladistic basis.

One of the scientific centres which first interpreted cladistics as an innovative system for phyletic reconstructions was the palaeontology section of the British Museum (Natural History). Here, in the 1960s, the new methodology was enthusiastically accepted, and became part of the museum's culture and, at the end of the decade, made its appearance in the museum's displays: in 1979 a permanent exhibit on dinosaurs was set up and in 1980 an exhibit was opened to the public on the evolution of man, both of which used Hennig's systematic. The intention was to introduce the new philosophy to the general public, as indicated by the pedagogic and didactic approach in the catalogues which accompanied the exhibits. ${ }^{26}$

The entry of cladistics in the London museum's displays raised an fundamental problem, since the absence of a temporal dimension removes any historic reconstruction capacity from Willy Hennig's phylogenetic systematics, and relegates the results of cladistics to the level of an atemporal chronicle. It was precisely this incapacity that led to considerable criticism of the two London museum's exhibits, which generated a heated debate that was played out for the most part in the pages of Nature, thanks in particular to the rebel spirit of the English palaeontologist, L.B. Halstead. ${ }^{27}$ More specifically, he criticised the fact that the exhibits showed relations between groups, leaving any direct research of ancestors out of consideration. This led, for example, to the paradox of denying, in the exhibition on human evolution, any direct ancestor-descendant link between Homo erectus and Homo sapiens. ${ }^{28}$ The polemics following these exhibits were rounded off with an anonymous editorial in Nature that questioned the validity of cladistics as a method for presenting evolution in museums. ${ }^{29}$

Despite these criticisms, cladistics has become a common feature of palaeontological exhibits in natural history museums. Ralph Appelbaum, the well-known designer, told me some years ago that every time he is commissioned to arrange an exhibit intended to illustrate the evolution of organisms, his clients ask him to adopt a cladistic approach. This has happened in many

26 Anonymous (1979), Dinosaurs and their living relatives, British Museum (Natural History), Catalogue of the Exhibit.

27 Halstead, L.B. (1980), Museum of errors, Nature, pp. 208, 288.

28 TASSY, P. (1995), Le cladisme, le musée et l'intérêt du public. In HinARD, F., La systématique et les musées, Dijon, Ocim, pp. 39-46.

29 Anonimo (1981), Cladistics and evolution on display, Nature, 292, pp. 395-396. 
museums. Appelbaum himself has used cladistics in his renewal of the exhibit of fossil mammals in the American Museum in New York, saying that he is convinced that the genealogical tree in the form of cladogram is an approach that makes evolution understandable to the public at large, since its construction is analogous to the construction that each individual carries out when drawing up his own genealogical tree..$^{30}$

Personally, I do not share Appelbaum's conviction and I feel that the cladistic methodology is not appropriate for museum exhibits. Since it does not take into account any temporal distribution of organisms, it is able to reconstruct only relations between groups and the serialisation of such relations i.e. the dichotomous subdivisions that constitute the genealogical tree of life. As the French cladist Pascal Tassy has written

«L'arbre phylogénétique cladistique ne contient qu'un seul type d'information : la séquence de branchements, qui n'est autre que l'histoire de l'apparition des lignées. La dimension chronologique est implicite; l'arbre illustre l'ancienneté relative des ancêtres respectifs des groupes subordonnés. Mais l'échelle du temps peut ne rester qu'implicite. La structure des relations de parenté est exprimée mais non l'extension dans le temps géologiques, l'extension stratigraphique des taxons impliqués.» ${ }^{31}$

In a certain sense the systematics that rise from the cladistic approach is a systematics that is only spatial, similar to the pre-evolutionist one, since it photographs the relations existing in the natural world, combining past and present. It is a phylogenetic systematics to the extent that it constructs sequences of appearances of features corresponding to relations between monophyletic pairs, arranging them in accordance with a certain sequence, whose direction with reference to time is not always easy to establish. In the cladogram, which is the result of a cladistic analysis, the known and analysed taxa are all placed on the same plane i.e. on the same level of importance; there are no intermediary forms between these taxa and, above all, one presumes that the ancestral forms which gave rise to the dichotomies are always unknown. In the cladogram no taxon rise therefore directly from another taxon.

The cladistic analysis therefore makes it possible to establish relations that have arisen between taxa, but only rarely is it able to say when or why such relations were established. Its independence of time and the exclusion of direct relations between organisms ensure that cladistics is essentially lacking in

30 Appelbaum, R. (1997), Progettare il museo del XXI secolo. In Basso Peressut, L., I musei della natura tra storia e progetto, Bologna, Clueb, pp. 236-242.

31 TASSY, P. (1991), L'arbre à remonter le temps, Christian Bourgois Éditeur, pp. 145-146. 
any narrative capacity. It can perhaps reconstruct a history in general terms, but it cannot narrate that history.

An example of this narrative incapacity can be seen in the illustration of the origin and initial diversification of reptiles, carried out using a cladistic approach by Joel Cracraft ${ }^{32}$ in an article in $1986 .{ }^{33}$

The result of Cracraft's study — not realised for museum purposes, though it would be interesting to see it transposed within a museum exhibition- is a cladogram that summarises his phylogenetic hypothesis.

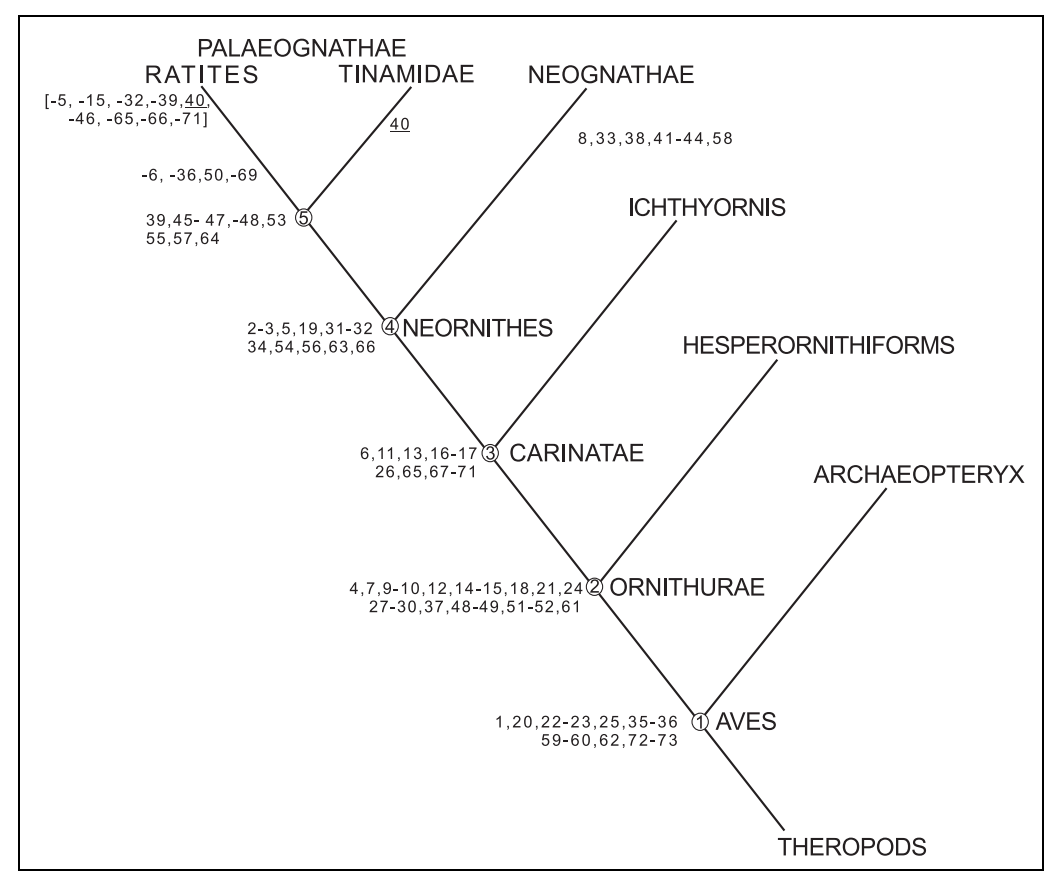

Figure 1. The cladogram, generated by Cracraft's study.

At the lowest point there are the theropod dinosaurs from which everyone agrees that birds are derived. From the theropods a direct straight line heads

32 Joel Cracraft is one of the most ardent supporters of the cladistic methodology and one of those most responsible for its affirmation in the palaeontolgical field. See: CRACRAFT, J. \& Eldredge, N. (1979), Phylogenetic Analysis and Paleontology, Columbia University Press.

33 Cracraft, J. (1986), The origin and early diversification of birds, Paleobiology, 12, pp. 383-399. 
upwards and to the left, along which are marked some nodal points corresponding to the appearance of new characters. All the representatives that are found above a given point have the characters that appear in that particular nodal point. Thus, for example, in nodal point 1, the new characters include the appearance of feathers (character no. 1), the presence of the furcula (no. 20), the complete fusion of the astragalus and the heel-bone (no. 22), and so on. This point marks the origin of birds: all the forms above it are to be classified as Aves. From each nodal point a line starts at the end of which there is a taxon (of different systematic level) which comprises the forms that have the characters that appeared in that nodal point plus the characters of the previous nodal point, but not those of the subsequent nodal point. Thus, for example, the Hesperornithiformes have all the characters of Archaeopteryx (nodal point 1), plus those of nodal point 2; Ichthyornis has the characters appearing in nodal points 1 and 2, plus those appearing in nodal point 3, and so on. From the systematic point of view come out a succession of taxa each included within the other like a series of Chinese boxes. In cladistic terms, i.e. always presuming that evolution proceeds by dichotomous divisions, the diagram must be read by saying that Archaeopteryx represents the sister group of all other birds (Ornithurae), the Hesperornithiformes the sister group of the Carinatae, Ichthyornis represents the sister group of the Neornithes, the Neognathae are the sister group of the Palaeognathae. This does not correspond to a historic narration. It is simply a listing of relationships, on the basis of a succession of appearances of new characters. It would not become a narration even if we provide a direction for this succession, since it contains only one aspect of the information that is essential for a narration: how the events occurred.

It is therefore clear that when it comes to the reconstruction of the history of life the cladistic analysis is able to provide only the first level of knowledge i.e. knowledge of possible relations between groups. These relations between groups do not constitute the history of the groups themselves. History is something else, it is based on relations between causes and effects and on sequences of facts that explain not only how, but also why, and above all the when of events. As regards the history of life, it can be reconstructed if the appearances of new feautures can be placed in relation to ecological, ethological, geographic or geological causes which gave rise to them, and this can be achieved only if one includes the temporal dimension which makes the relationship between causes and effects operative.

There are only two ways of exhibiting the history of evolution in a museum: it can be done chronologically, showing, as Georges Cuvier would have done, had he been an evolutionist, era after era, or period after period, 
the succession of different fauna and flora, without focusing attention on the phyletic relationships and the relationships of descent between organisms; or one can carry it out phylogenetically, as Albert Gaudry or Henry Fairfield Osborn did, highlighting precisely these relationships and connections. In the latter case the display of evolutionary history can only correspond to the construction of a genealogical tree, which nevertheless, to be understandable, must have narrative capacity, which occurs if relationships of cause and effect between events are identified i.e. relationships of descent between ancestors and descendants, and if these events are placed in a chronological sequence. Now, since two of the features of phylogenetic systematic are (1) the denial of the possibility of defining relations (only indirect relations can be defined) and (2) the denial of the importance of the temporal succession of these relations, the genealogical tree that can be used in the narration of evolutionary history cannot be a cladogram. It is therefore clear that, the more palaeontology depends on phylogenetic systematic, the more it will lose not just its ability to reconstruct the history of life in all its aspects, but above all its ability to narrate this history to others which, unless I am very much mistaken, is the aim of any history discipline.

The method of reconstructing relationships based on a comparison between pairs of entities is not an original invention of Willy Hennig, and it is not an approach exclusive to the natural sciences. The reconstruction of forms of language through comparative linguistics between pairs of forms described by De Saussure has significant similarities with the cladistic system. In addition, when I state that the simple identification of points of bifurcation between two phyletic lines does not in itself have any reconstruction capacity, I am not doing anything other than agreeing with what De Saussure argued i.e. that comparison as such is incapable of historic reconstructions if the results of these comparisons are not put in historical perspective and in relation with every other fact that is useful in understanding their causes.

«The first error, containing the germ of all the others - De Saussure wrote- is that comparative grammar, in its enquiries (...) has never asked what the comparisons that it formulated meant, what the relations it discovered signified. It was exclusively comparative instead of being historic. Undoubtedly comparison is a necessary condition for any historic reconstruction. But of itself it does not make it possible to arrive at a conclusion (...) This exclusively comparative method carries with it an entire mass of erroneous conceptions that do not correspond to reality and which are extraneous to the effective conditions of any language.. ${ }^{34}$

34 De Saussure, F. (2000), Corso di linguistica generale, Bari, Laterza, p. 12. 


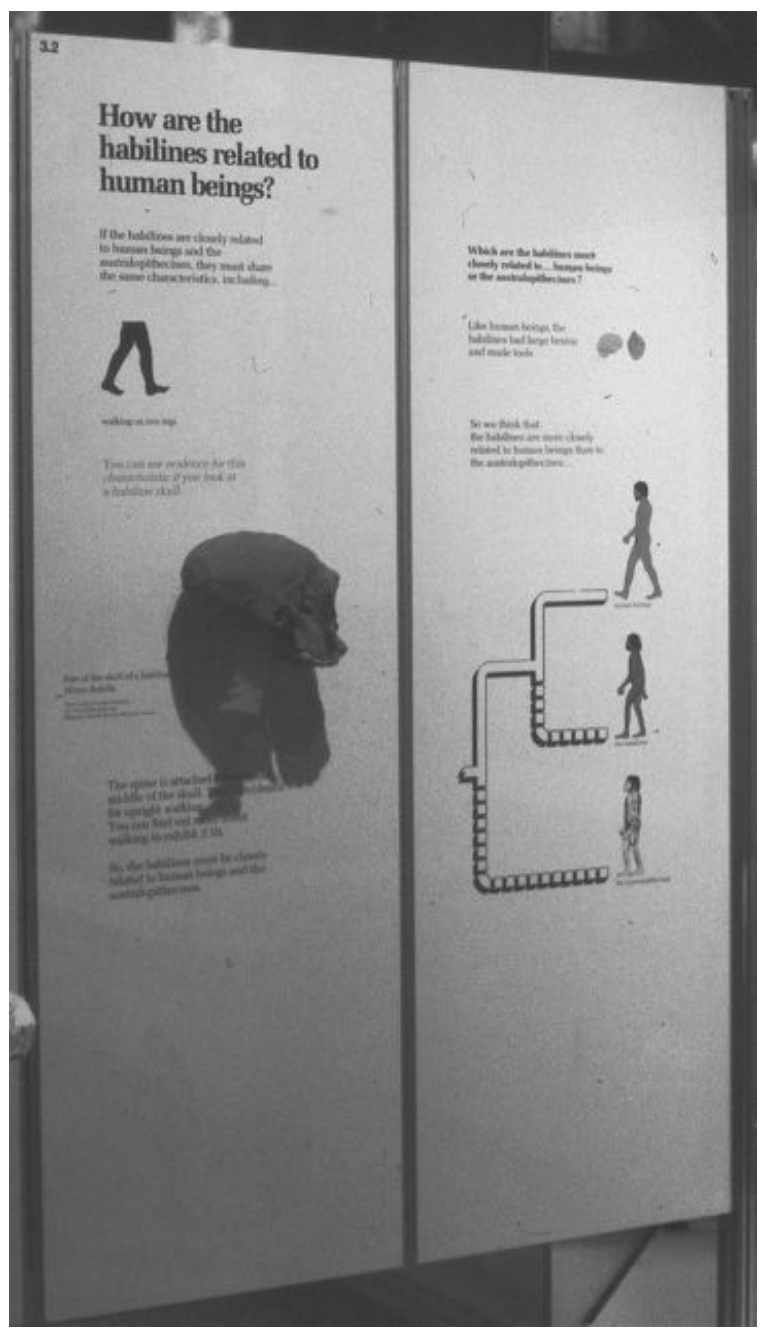

Figure 2. Two panels from the exhibit on evolution of man in The Natural Museum, London. On right side the cladogram representing the relationships between modern man, Homo habilis and Autralopithecine (Pinna, 1989).

Fecha de recepción: 20 de marzo de 2009

Fecha de aceptación:15 de julio de 2009 